\title{
CLINICAL STUDY OF PRESTONAL AS A MUSCLE RELAXANT IN ANAESTHESIA: A PRELIMINARY REPORT ${ }^{*}$
}

\author{
Harold R. Griffith, M.D, F.R C.P.(c), F.F.A.R.C.s., Wrlliam G. Cullen, M.D., \\ and Peter Welt, M.D **
}

Ir is now over fourteen years since a relaxant drug was first employed in clinıcal anaesthesia (1). During this period of years, many different drugs have been introduced into anaesthesia because of their abslity to relax skeletal muscles. Before considering the study of another such preparation, let us contemplate a few of the basic principles involved in an evaluation of new drugs in anaesthesia, as suggested by Melville (2).

\section{Effectiveness}

Is the drug really effective for the specific purpose for which it is being studied? Is it superior or inferior to the known agents used for the same purpose? In answering these questions, individual differences in susceptibility to drugs must always be kept in mind. A critical investigation of 10 or 20 cases, involving a more or less individualized and detailed study in each case, might be a more fruitful approach to the problem than a superficial and less critical study of 100 or 200 cases.

\section{Safety}

Is the drug free from injurnous effects in the body?

\section{Dosage}

In making an evaluation, it is wise to start with minumal doses and gradually increase as the effects are observed. The intravenous method of administration is most easily controlled.

\section{Influence of Other Drugs used in Anaesthesia}

"Combination" does not necessarily mean "potentiaton"

During the last two years, Rudolf Frey (5) of Heidelberg, Germany, has studied various new drugs proposed as relaxants in anaesthesia:

(1) Desoxxdauruzin-rejected because of too weak action and too heavy histaminic side effects.

(2) Praparat 9909-rejected because of depressive action on the respuratory centre.

(3) Belladonninbromaethylat-rejected because of central respuratory disturbances.

'Presented at the Annual Meeting of The Canadian Anaesthetists' Society, Mont Tremblant, P Q , June 18-20, 1956

"From the Department of Anaesthesia, Queen Elizabeth Hospital of Montreal, and McGill Unversity, Montreal, Quebec. 
(4) Various other test preparations-rejected because of considerable increase in pulse rate.

(5) Dioxahexadekaniumbromid, Prestonal (Geigy)-recommended.

Frey has now used Prestonal in clinical anaesthesia in over 1000 cesses, although less than a third of these cases have been studied in detail.'

\section{Chemical Properties}

The chemical formula for Prestonal has been outlined as follows:

$\mathrm{N}, \mathrm{N}, \mathrm{N}^{\prime}, \mathrm{N}^{\prime}$-Tetramethyl-N, N'-bis-(carbopropoxymethyl)-3, 14-dioxahexadecane-1, 16-diammonium bromide<smiles>C=[14C](C)CCC=O</smiles>
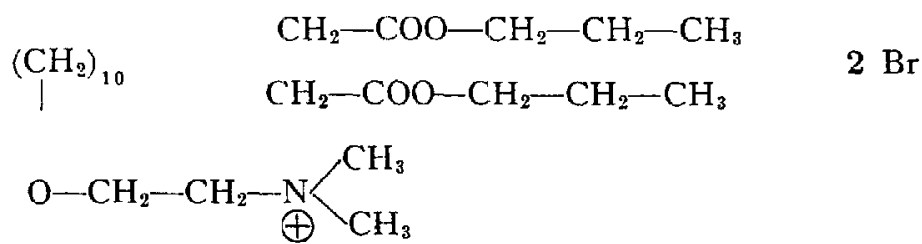

Prestonal differs from the other such compounds in having a much longer chain between the two quaternary ammonium groups (molecular weight $=678.6$ ). The substance is a colourless crystalline powder, easily soluble in water, with a melting point of $146^{\circ} \mathrm{C}$. An aqueous solution is practically neutral, but at a $\mathrm{pH}$ of 7.4 and $37^{\circ} \mathrm{C}$., Prestonal is spontaneously decomposed by hydrolysis to an extent of 50 per cent in 40 minutes. At a higher $\mathrm{pH}$ the half-life becomes shorter, at a lower $\mathrm{pH}$, longer. Consequently, the J. R. Geigy Company of Basle, Switzerland, have prepared the product Prestonal Geigy (G 25, 178) in a 1 per cent solution, with $100 \mathrm{mg}$. in each $10 \mathrm{ml}$. ampoule (i.e., $10 \mathrm{mg}$. per ml.). This solution has been adjusted to a $\mathrm{pH} 32$ approximately and has proven to be stable, even when stored for a considerable period.

When $50 \mathrm{mg}$. of this solution of Prestonal are mixed in a syringe with 375 or $500 \mathrm{mg}$. of 2 or 3 per cent thiopental respectively, a milky solution results. However, if this solution is left quietly on the table for a few minutes, it readily becomes very clear and is satisfactory for use.

\section{Histamine Responses}

Since some muscle relaxants are thought to release histamine in yarious degrees (3), simple observations were made on four of ourselves, using the method of small intracutaneous wheals. The amount and the speed of appearance of redness and induration were observed, using the following solutions:
1. Prestonal
(10 mg. per ml.)
2. d-tubocurarine
( $3 \mathrm{mg}$. per $\mathrm{ml}$ )
3. Succinylcholine
( $20 \mathrm{mg}$. per ml.)
4. Decamethonium
5. N-saline
( $1 \mathrm{mg}$. per ml.)

The results of these skin tests (see Table I) indicate that Prestonal and 
TABLE I

Skin Sensitruity Tests (Humans)

\begin{tabular}{|c|c|c|c|c|c|c|c|c|c|}
\hline & \multicolumn{2}{|c|}{ Subject A } & \multicolumn{2}{|c|}{ Subject B } & \multicolumn{2}{|c|}{ Subject $\mathrm{C}$} & \multicolumn{2}{|c|}{ Subject D } & \multirow{2}{*}{$\begin{array}{c}\text { Average } \\
\text { grade }\end{array}$} \\
\hline & Wheal & Redness & Wheal & Redness & Wheal & Reciness & Wheal & Redness & \\
\hline I. Prestonal & 4 & 6 & 5 & 5 & 4 & 6 & 5 & 5 & 5 \\
\hline II d-Tubocurarine & 4 & 3 & 3 & 4 & 4 & 4 & 3 & 4 & 4 \\
\hline III Succinylcholine & 2 & 2 & 1 & 3 & 2 & 2 & 2 & 3 & 2 \\
\hline IV. Decamethonium & 1 & 2 & 1 & 1 & 0 & 1 & 1 & 2 & 1 \\
\hline V Normal salıne & 0 & 0 & 0 & 0 & 0 & 0 & 0 & 0 & 0 \\
\hline
\end{tabular}

Reactions were graded from 0 to 6 , considermg both the immediate and delayed responses, following small intracutaneous injections

d-tubocurarine produce skin reactions of the highest order with Prestonal even exceeding d.T.c in this respect. Succinylcholine produced a reaction less than half that of the former two drugs, whereas decamethonum produced a positive result of the lowest order The normal saline solution produced a negative response in all cases.

When decamethonıum was first introduced into anaesthesıa, this very low histamine response was halled as one of its advantages over $\mathrm{d} T \mathrm{c}$. (4).

It was observed sharply by all our volunteers that intracutaneous Prestonal produced an immediate and somewhat prolonged "stnging" sensation and that succinylcholıne produced a very mild and short "sting " Comparatively speakıng, the other injections were painless The acidity or the vehicle may be the cause of the "stinging" response.

\section{Cuinical Study of Prestonal}

Our clinical observations and impressions will, of necessity, be limited. We have used Prestonal as a muscle relaxant during anaesthesia for surgical procedures on only twenty-six patients.

In Table II the details of the cases are presented. It will be noted that the ages ranged from 14 to 78 years (see Tables II and III).

Of the 26 cases, 17 patients had abdominal surgery and thus required relaxation for major procedures both in the upper and in the lower abdomen.

Eight patients were postured in the Trendelenburg position for gynaecology.

As all of the patients (except one, who was: undergoing bronchoscopy) were orally intubated by direct vision using a Macintosh laryngoscope, conditions for this procedure could be evaluated.

The anaesthetic agents and methods were quite uniform. Two per cent thiopental solution, in doses ranging from 100 to $500 \mathrm{mg}$, was used for induction in all cases and cyclopropane or nitrous oxide for maintenance.

Prestonal was given intravenously in various concentrations varying from 0.05 to 1 per cent solutions and of course in variable dosage, ranging from 40 to 265 mg. (see Table IV). 


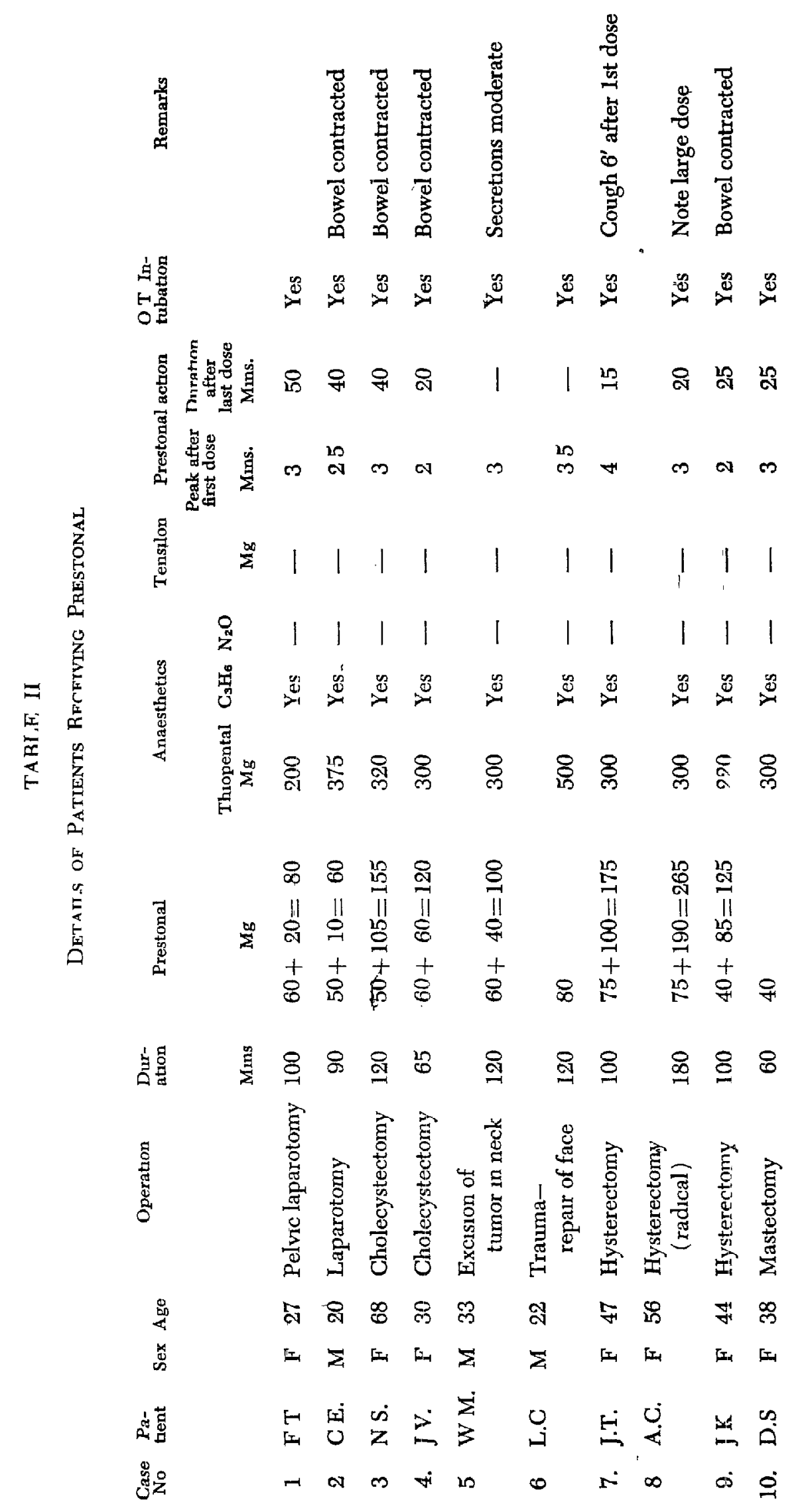




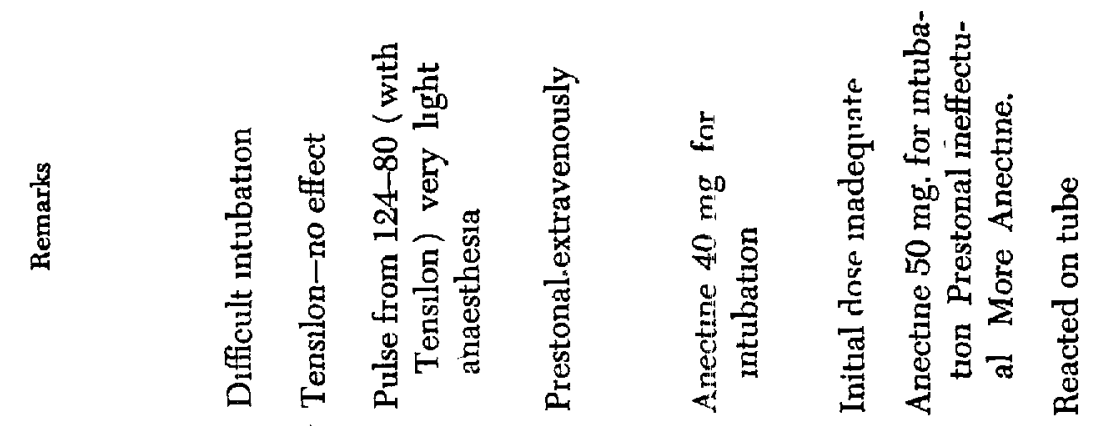

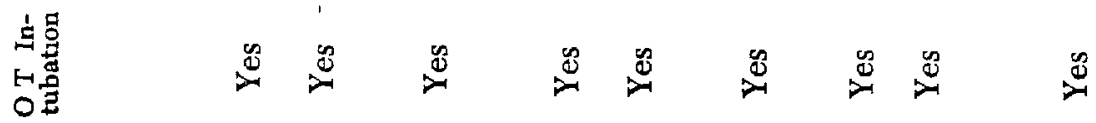

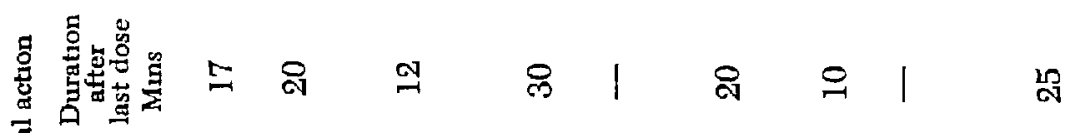

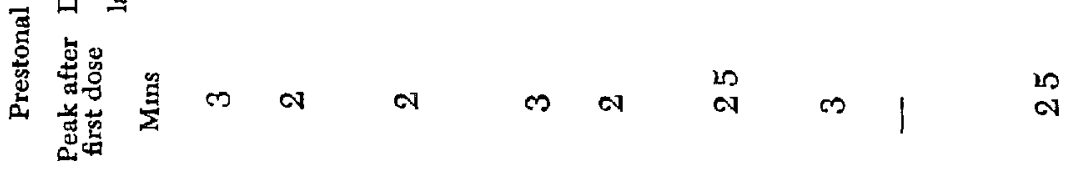

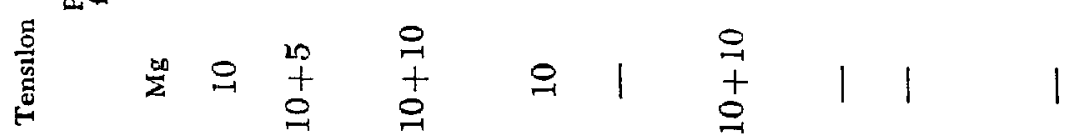

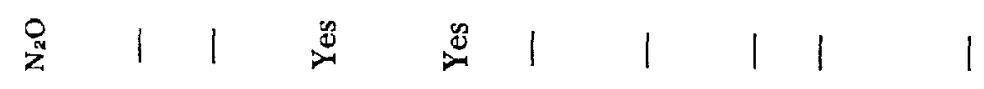

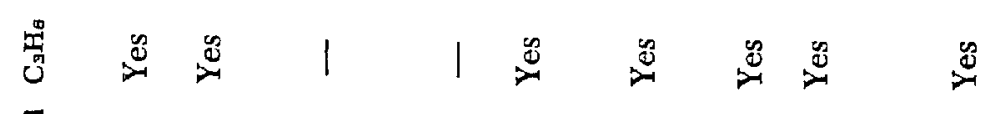

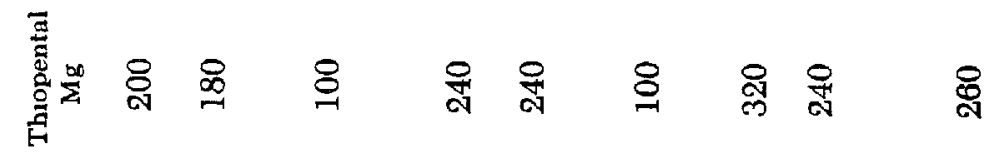

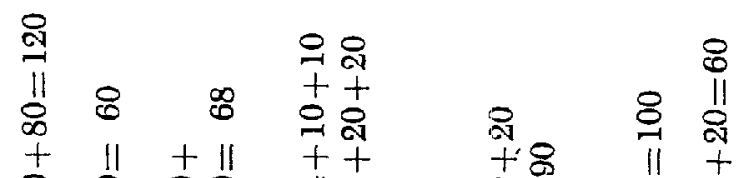

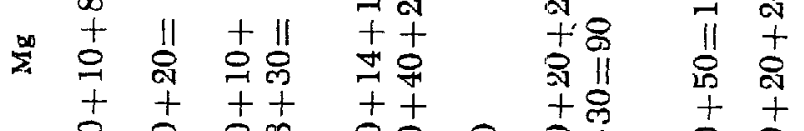

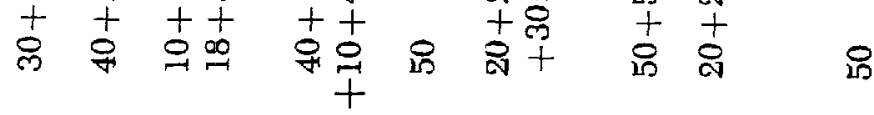

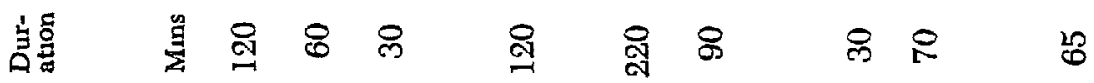

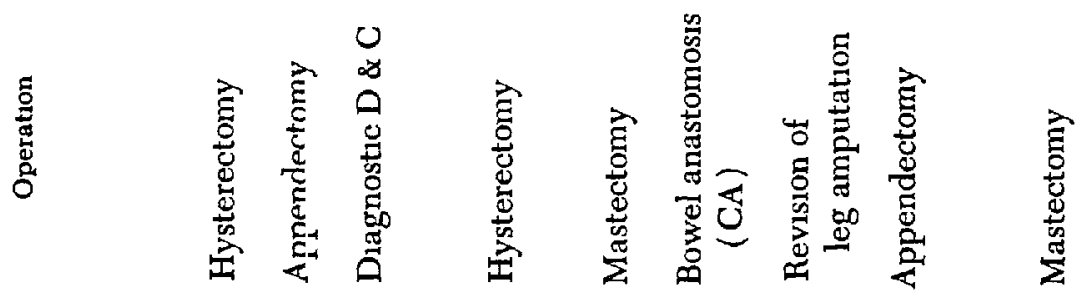

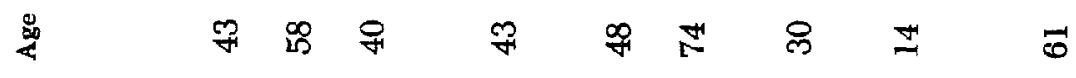

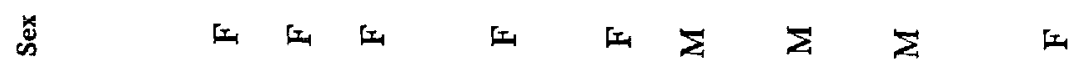

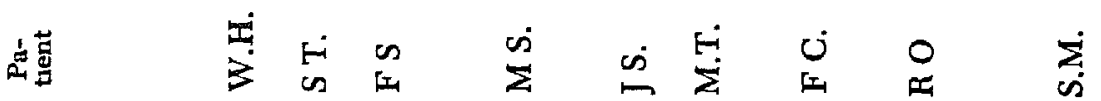

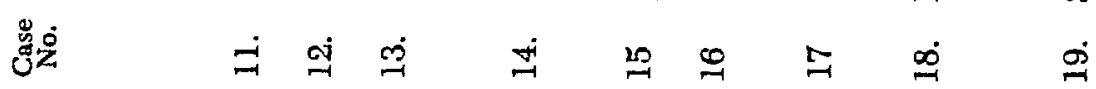




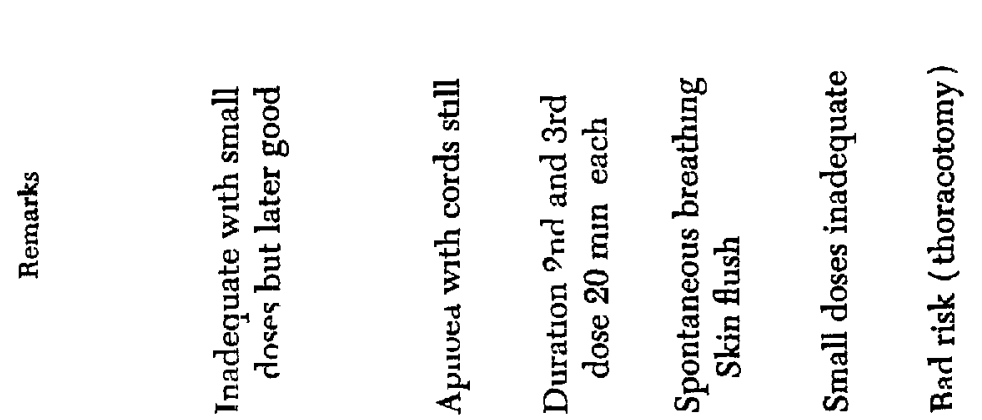

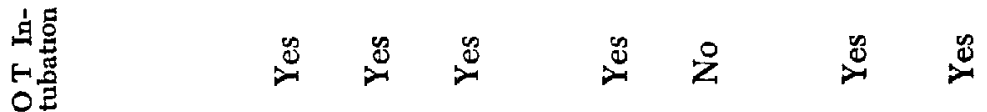

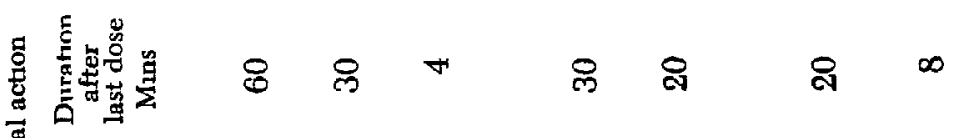

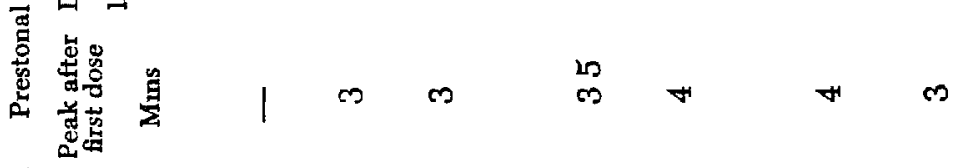

$$
\begin{aligned}
& \begin{array}{lllllllll}
\frac{5}{2} & \infty & 1 & 1 & 1 & 1 & 0 & 1 & 1
\end{array}
\end{aligned}
$$

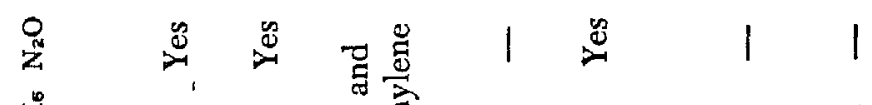

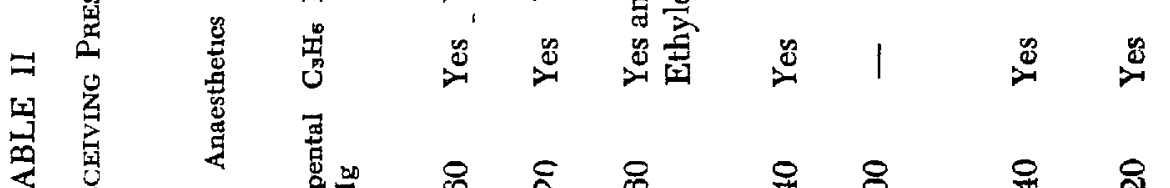

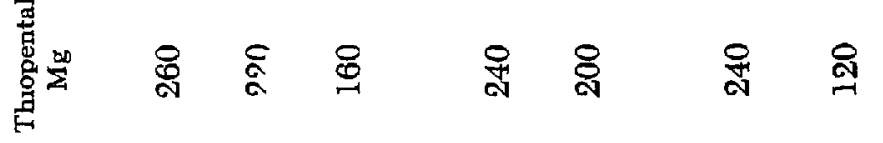

$$
\begin{aligned}
& \text { 童 }
\end{aligned}
$$

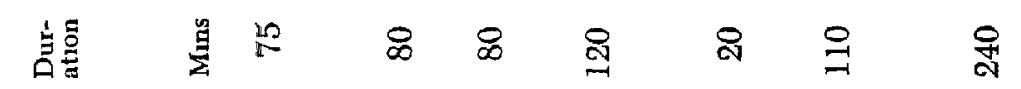

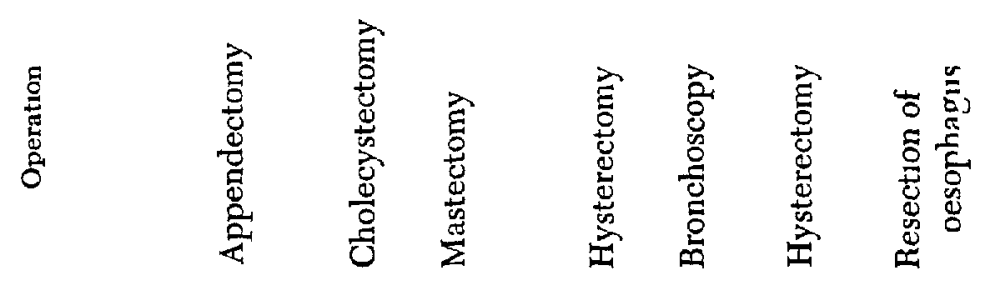

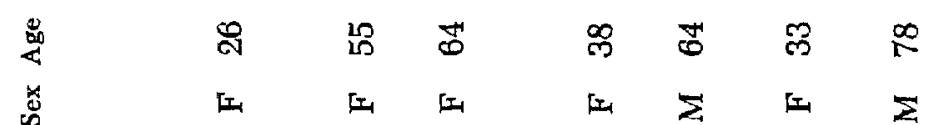

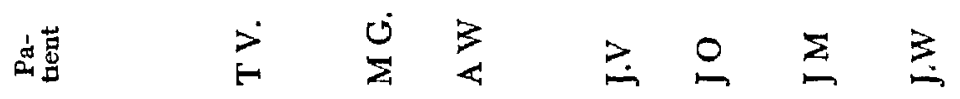

$$
\begin{aligned}
& \text { รั้ำ ส ส }
\end{aligned}
$$


TABLE III

Age Distrubution

\begin{tabular}{|c|c|c|}
\hline \multicolumn{2}{|c|}{ Age } & Number of cases \\
\hline \multicolumn{2}{|c|}{$10-19$ years } & 1 \\
\hline $20-29$ & 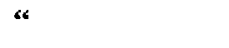 & 4 \\
\hline $30-39$ & “ & 6 \\
\hline $40-49$ & “ & 6 \\
\hline $50-59$ & $“$ & 3 \\
\hline $60-69$ & “ & 4 \\
\hline \multirow[t]{2}{*}{$70-79$} & $“$ & 2 \\
\hline & Total & $\overline{26}$ \\
\hline
\end{tabular}

TABLE IV

Prestonal Range of Dosage and Concentration

\begin{tabular}{|c|c|c|c|c|c|c|c|}
\hline \multirow[t]{2}{*}{$\begin{array}{l}\text { Case } \\
\text { No. }\end{array}$} & \multicolumn{2}{|c|}{$\begin{array}{c}\text { Intubation } \\
\text { dose }\end{array}$} & \multicolumn{2}{|c|}{$\begin{array}{l}\text { Maintenance } \\
\text { dose }\end{array}$} & \multirow{2}{*}{$\begin{array}{c}\text { Total } \\
\text { dose } \\
\text { Mg }\end{array}$} & \multirow{2}{*}{$\begin{array}{l}\text { Duration of } \\
\text { operation } \\
\text { minutes }\end{array}$} & \multirow[t]{2}{*}{ Remarks } \\
\hline & $\mathrm{Mg}$ & Conc'n. & $\mathrm{Mg}$ & Conc'n. & & & \\
\hline 1 & 60 & 18 & 20 & $1 \%$ & 80 & 100 & \\
\hline 2 & 50 & 1 & 10 & 1 & 60 & 90 & \\
\hline 3 & 50 & 1 & 105 & 005 & 155 & 120 & \\
\hline 4 & 60 & 1 & 60 & 005 & 120 & 65 & \\
\hline 5 & $60+40$ & 1 & None & & 100 & - & \\
\hline 6 & 80 & 1 & None & & 80 & - & \\
\hline 7 & 75 & 1 & 100 & 005 & 175 & 100 & \\
\hline 8 & 75 & 1 & 190 & 005 & 265 & 180 & \\
\hline 9 & 40 & 1 & 85 & 010 & 125 & 100 & \\
\hline 10 & 40 & 1 & None & & 40 & - & \\
\hline 11 & $30+10$ & 1 & 80 & 010 & 120 & 60 & \\
\hline 12 & 40 & 1 & 20 & 1 & 60 & 60 & \\
\hline 13 & 30 & 1 & 48 & 1 & 68 & - & Special case \\
\hline 14 & 40 & 1 & 124 & 1 & 164 & 120 & \\
\hline 15 & 50 & 1 & None & & 50 & - & \\
\hline 16 & None & & 90 & 1 & 90 & 90 & $\begin{array}{l}\text { Intubated with } \\
\text { Succinylcholine }\end{array}$ \\
\hline 17 & $50+50$ & 1 & None & & 100 & - & \\
\hline 18 & None & & 60 & 1 & & 70 & $\begin{array}{l}\text { Succinylcholine before \& } \\
\text { after Prestonal }\end{array}$ \\
\hline 19 & 50 & 1 & None & & 50 & - & \\
\hline 20 & $\begin{array}{l}20+30 \\
+20+30\end{array}$ & 1 & None & & 100 & 75 & Inıtal doses inadeqùate \\
\hline 21 & 50 & 1 & 30 & 1 & 80 & 80 & \\
\hline 22 & 60 & 1 & 20 & 1 & 80 & - & $\begin{array}{l}\text { 2nd dose to cover light } \\
\text { anaesthesia }\end{array}$ \\
\hline 23 & 60 & 1 & 160 & 1 & 220 & 120 & \\
\hline 24 & $50+20$ & 1 & & & & 20 & Bronchoscopy \\
\hline 25 & 50 & 1 & 105 & 1 & 155 & 110 & \\
\hline 26 & 60 & 1 & None & & 60 & - & \\
\hline Aver & 60 & & 80 & & 140 & 100 & \\
\hline
\end{tabular}




\section{Discussion OF ResUlts}

\section{Conditions for Intubation}

It was consistently easy to obtain good conditions for intubation if an adequate dose was given. With doses of 30 or $40 \mathrm{mg}$. the jaw muscles and those of the pharynx might be adequately relaxed to expose the glottis but the vocal cords would be actively moving as spontaneous breathing was well maintained. If the upper respiratory passages were allowed to become obstructed, this spontaneous diaphragmatic breathing might cease and the patient appear apnoeic. This was demonstrated in a bronchoscopy cas,e, where apnoea prior to the passage of the bronchoscope was followed by active diaphragmatuc breathing during the examination. After the bronchoscope was removed, apnoea again occurred with momentary cyanosis, owing to upper respiratory obstruction. Thus upper respiratory paralysis occurred concurrently with active diaphragmatic breathing, in spite of doses of $50 \mathrm{mg}$. $+20 \mathrm{mg} \quad(=70 \mathrm{mg})$ of Prestonal prior to bronchoscopy. This patuent was'reacting somewhat before his block had worn off but, on later questioning, remembered nothing before he was lifted onto his bed a few minutes later. The surgeon was pleased to have his patient breathing spontaneously during the examination

In the average intubation case, a minimum dose of $60 \mathrm{mg}$. of drug produced good conditions for intubation. Ir most of these cases apnoea and maximal relaxation occurred 2 or 3 minutes after injection and lasted from 6 to 8 minutes more.

\section{Abdominal Relaxation}

In all but one of the abdominal cases it was possible to obtain good relaxation of the abdominal muscles, if an adequate dose, etther singly or by rapid drip, was given On the other hand, intermittent small doses of 10 or $15 \mathrm{mg}$, even if given repeatedly and at 3 or 4 minute intervals, might never produce good results. It seems that 30 or $40 \mathrm{mg}$. as the mitial dose was necessary to obtain relaxation, whereupon additional doses of $20 \mathrm{mg}$ intermittently usually proved adequate for maintenance. This finding was comparable to what we have found with d.T.c.

The dose of Prestonal approximates about six times the dose of $\mathrm{d}$ T.c which we were accustomed to use in similar cases.

\section{Pulmonary Ventilation}

To avoid the possibility of obstruction in the upper respiratory passages, an endotracheal tube is necessary. In addition the minimal amount of resistance to spontaneous ventllation is obtained. We could find no evidence of particular obstruction in the lower respiratory passages which might be considered to be spasm due to histamine-release. Such cases have been reported with d.T.c. but have been very rare in our experience with the latter drug.

Nevertheless, tracheal reactions from stimulation, such as mild cough or so called "bucking on the tube" did occur fairly often. However, such responses are probably not related to histamine.

In most of our abdominal cases, good relaxation was associated with very 
depressed ventilation. Usually controlled ventilation was established either manually, or automatically with the Jefferson Ventilator.

However, in a few cases, and especially if nitrous oxide was used instead of cyclopropane, quite adequate spontaneous ventilation was maintained during the period of relaxation. It was difficult to gauge the dose just right to provide such a situation. Possibly if more cases were handled with nitrous oxide, spontaneous ventilation might be more frequently obtained.

\section{Changes in Pulse and Blood Pressure}

In over 90 per cent of cases, the systolic blood pressure remained steady within a range of $10 \mathrm{~mm}$. of mercury and the pulse variation was within ten points per minute.

In one case, the pulse rose from 80 to 110 per minute after $100 \mathrm{mg}$. of 1 per cent Prestonal had been given within one minute. It soon returned to normal. Similarly, in a patient in a very light stage of anaesthesı (after only $100 \mathrm{mg}$. of Thiopental) Prestonal, in a dose of $70 \mathrm{mg}$. within two munutes, resulted in an increase of pulse rate from 84 to 124 . In this case, the pulse rate was readily reversed to 80 with Tensilon ( $10 \mathrm{mg}$. $+10 \mathrm{mg}$.).

Thus it is fair to say that a relatively large dose of Prestonal, with or without very light anaesthesia, may result in tachycardia which is probably due to a block of the cardiac vagal fibres, as occurs very frequently with gallamine (Flaxedil).

There were no cases showing hypotension after this drug but an occasional one showed a mild transitory rise in blood pressure.

If the drug is not given faster than $2 \mathrm{mg}$. per second, there will seldom occur any change in pulse or blood pressure.

\section{Period of Action}

The drug seems to reach its peak action after about two minutes, at which time apnoea usually appears. Occasıonally relaxation seemed maximal three minutes after the 1 per cent solution was given into the intravenous tubing of a previously set-up infusion.

Although the duration of action of a single dose was difficult to evaluate, it appeared to be about six to eight minutes.

Nevertheless, after repeated doses or after dilute solutions were given by continuous infusion and then stopped, the period of apnoea lasted for a further 25 or 30 minutes. Thus there may well have been some cumulative effect. During this apnoeic period there is usually persistently good relaxation. Near the end of the period it is common to see tight spastic jaw muscles before the respuration is spontaneously resumed.

We have not seen cases of very prolonged apnoea "with Prestonal, such as have been seen many times associated with the combination of pentothal, succinylcholine, and controlled ventilation.

\section{Antagonists and Mode of Action}

Frey (5) has reported several cases where the myoneural block of Prestonal was reversed or antagonized by $5 \mathrm{mg}$. of pyridostigmine, rather more effectively 
than by neostigmine (prostigmine). However, neostigmine produced some antagonism. Thus he concluded that the block was probably of the antidepolarizing or competitive type. Recently, other investigators have challenged this idea and suggest that it is probably the "mixed block" type of relaxant.

On six occasions we have tried to reverse the action of Prestonal with Tensilon, using an $1 / \mathrm{V}$ dose of $10 \mathrm{mg}$., repeated in 5 or 10 minutes.

Although tachycardia, when present after Prestonal, could be reversed by Tensilon, we could not see any sharp reversal of the block. However, it did seem that the apnoeic period after the last dose of Prestonal was somewhat shortened. This may indicate some interference with the block and possibly a larger dose of Tensilon would have produced more conclusive results.

Thus our experience with Tensilon as an antagonist is not very convincing.

On two occasions we have intubated after thiopental and succinylcholine and then proceeded to give Prestonal for abdominal relaxation. With one patient-age $14-50 \mathrm{mg}$. succinylcholine had been used initially, and after $60 \mathrm{mg}$. Prestonal the relaxation was still very poor. Then an infusion of 01 per cent succinylcholine was turned on and immediately excellent relaxation was obtained. With the other patient-age 74-40 mg succinylcholme had been used for induction. Prestonal in doses of $20,+20,+20$ and $30 \mathrm{mg}$ was then given before relaxation was obtained and this patient was a thin elderly man with advanced malignancy in the stomach.

It thus appears that succinylcholine, inttally, definitely interferes with the Prestonal block but that subsequent doses of succinylcholine are still effective. Thus one might think that the Prestonal block is not of the depolarizing type. Otherwise these two drugs would probably by synergistic.

Consequently, our bit of evidence seems to support the theory that Prestonal belongs to the "mixed block" type of relaxant Clinically, it gives many of the responses which were seen after $\mathrm{d}$.T $\mathrm{c}$

\section{Other Observations}

(a) In no case did we see any muscle fasciculations after the injection of the drug, such as are commonly observed after injecting succinylcholine

(b) In several of the cases for abdominal surgery, the small bowel appeared to be well contracted, which may often facilitate the surgical procedure. This observation has also been made after succinylcholıne.

(c) In contrast to the frequent occurrence of excessive salivary secretions after certain other relaxants, the patients receiving Prestonal were usually notably dry.

(d) The condition of the vocal cords was usually not completely quiescent, and there occasionally followed a minor stimulatory reaction in the cords and trachea after the endotracheal tube was placed. This reaction was never troublesome.

(e) There was no evidence in our cases of intravenous or perivenous irritation following the injection of Prestonal in the various concentrations mentioned. In one of our cases, the site of the infusion needle in the arm, during a hysterectomy, was completely covered with drapes and was not only out of sight but out of reach. After a total dose of over $80 \mathrm{mg}$. of 1 per cent Prestonal in amounts 
of 10 or $15 \mathrm{mg}$ each, the relaxation was still very unsatisfactory. Only then was it found that the needle was dislodged and the drug as well as the infusion fluid was passing extravenously. The area was infiltrated with 1 per cent procaine and there were no ill effects whatever.

( $f$ ) We were not too surprised to find, at least occasionally, some histaminelike patchy flushing in the skin of the face, neck, and chest areas of some of our patients. This response was associated with the larger doses of 1 per cent Prestonal given withm a short period of a few minutes.

\section{ConcLusions}

1. Prestonal is capable of producing good relaxation of skeletal muscles.

2. The duration of relaxation after a single dose is relatively short, probably between 6 and 8 minutes, but periods of relaxation up to 30 minutes may follow repeated doses or continuous infusion.

3. The block appears to be of the mixed type, and thus antagonists are not convincing.

4. The method of breakdown of the drug has not been established although hydrolysis by enzymes has been suggested.

5 No serious undesirable side-effects have been found thus far.

6. Although much more experience is necessary to evaluate this drug, Prestonal has some advantages over the currently popular relaxants. Only time can tell whether such advantages will overbalance the disadvantages" and thus create a place for this relaxant in anaesthesia.

\section{RÉSUMÉ}

Les auteurs présentent un rapport sur l'usage du prestonal comme myorésolutif dans 26 cas. Ce médicament peut produire un bon relâchement des muscles striés Après une dose unique, ce relâchement est d'une durée relativement courte, entre 6 et 8 munutes probablement, mass, sı les doses sont répétées ou si la drogue est administrée en infusion contınuelle, il peut exister des périodes de relâchement d'une durée allant jusqu'à trente minutes. Le type de blocage semble être varié aussi les antıdotes ne sont pas efficaces. Les auteurs n'ont pas établi comment est métabolisé ce médıcament, mass il semble qu’ll serait hydrolysé par des enzymes. Jusqu'ici les auteurs n'ont pas, non plus, décelé d'effets indésirables.

Bien que, pour faire une bonne évaluation de ce médicament, il soit nécessaire d'en faire usage sur un nombre de cas beaucoup plus considérable, il est possible d'affirmer que le prestonal possède certains avantages sur les myorésolutifs employés couramment. Seul le recul du temps pourra permettre d'affirmer si ces avantages l'emporteront sur les désavantages et si ce médicament pourra se créer une place comme myorésolutif en anesthésie.

\section{REFERENCES}

1 Griffith \& Johnson Anesthesiology 3 418-20 (July, 1942).

2 Melvirle, K I Canad Anaesth Soc J. 2.1 (1955).

3 Comroe, J H Jr. \& Drdpps, R. D. Anesthesiology 7 260-2 (May, 1946).

4 Harris, L C, Jr. \& Dripps, R D Anesthesiology 11 215-2j (March, 1950)

5 FreY, Rudolf. Proc. World Congress of Anesthesiologists (1955) 262-7. 